\title{
Giardiasis in Childhood
}

\section{Absorption Tests and Biochemistry, Histochemistry, Light, and Electron Microscopy of Jejunal Mucosa}

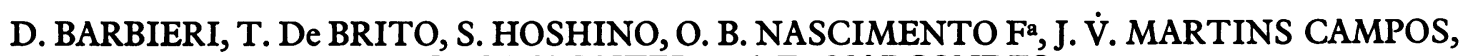 \\ G. QUARENTEI, and E. MARCONDES \\ From the Department of Paediatrics (Unit of Malabsorption Studies in Children), and Institute of Tropical Medicine, \\ University of São Paulo, Brazil
}

\begin{abstract}
Barbieri, D., De Brito, T., Hoshino, S., Nascimento Fa, O. B., Martins Campos, J. V., Quarentei, G., and Marcondes, E. (1970). Archives of Disease in Childhood, 45, 466. Giardiasis in childhood: absorption tests and biochemistry, histochemistry, light and electron microscopy of jejunal mucosa. Eleven symptom-free children with infestation by Giardia lamblia but without other diseases were studied by absorption tests and jejunal biopsy. Lipiodol and $\mathbf{D}$-xylose tests showed a mild degree of malabsorption. Light microscopy showed no tissue invasion in the jejunal mucosa.

The number and appearance of the villi were normal or almost normal, but the lamina propria was usually infiltrated by inflammatory cells. Electron microscopy showed an increased mucoid coat of the epithelial cells, branching and gaps in the microvilli, an increased number of cytoplasmic dense bodies, and intercellular spaces infiltrated with lamina propria inflammatory cells. Biochemical and histochemical studies of acid phosphatases, alkaline phosphatases, and succinic dehydrogenase showed no differences in enzyme activity of the jejunal epithelia before and after treatment. It is suggested that the malabsorption which occurs in giardiasis depends on several factors, such as blockade of the mucosa by the parasite, nutritional competition between host and parasite, and changes in the jejunal mucosa due to the presence of protozoa.
\end{abstract}

There have been many studies of the clinical features of giardiasis and the associated malabsorption (Véghelyi, 1940; Cortner, 1959; Court and Anderson, 1959; Ayres, 1960; Verri et al., 1965; Burdzińska-Golowin, Lewandowska, and Misiukowa, 1967) but much less information on the jejunal mucosal pattern (Cameron et al., 1962; Cantor et al., 1967). Electron microscopy was carried out on specimens taken from a mixed group of adult patients (Zamcheck et al., 1963; Yardley, Takano, and Hendrix, 1964; Takano and Yardley, 1965; Hoskins et al., 1967; Morecki and Parker, 1967; Brandborg et al., 1967).

It is difficult to evaluate the pathogenetic role of Giardia lamblia infestation in children, because of its frequent association with other intestinal parasites or forms of malnutrition. The present

Received 1 January 1970. study was therefore carried out with an asymptomatic and well-nourished group of children with a heavy infestation of $G$. lamblia but without other parasites. We examined absorption tests and the biochemistry, histochemistry, and light and electron microscopy of the jejunal mucosa in an attempt to elucidate the mechanism of malabsorption produced by the protozoa.

\section{Material and Methods}

The study was carried out on 11 asymptomatic children between the ages of 1 and 8 years, infested with G. lamblia, but presenting no evidence of malnutrition or any other form of parasitism. The following investigations were carried out before and after treatment : (1) stools were examined for parasites by conventional methods; (2) duodenal juice freshly prepared was examined directly for parasites; (3) D-xylose test was performed with a $5 \mathrm{~g}$. oral dose and 5 -hour urine collection. Xylose was chemically determined by the orcinal 


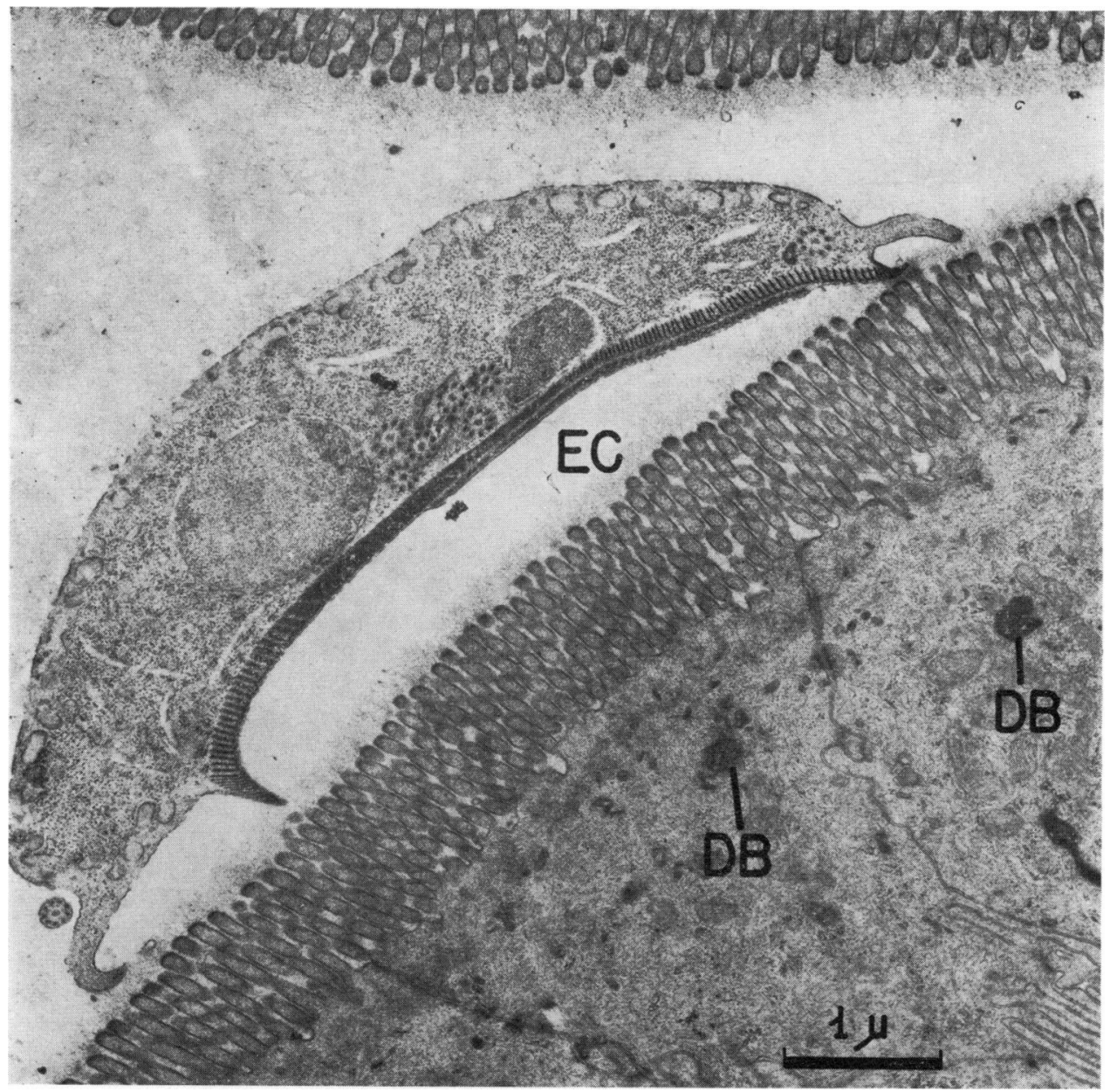

FIG. 1.-Electron micrograph showing detail of G. lamblia. Extraneous coat $(E C)$ increased in this area. DB designates few electron dense bodies in the epithelial cell cytoplasm.

method (Frankel and Reitman, 1963); (4) lipiodol absorption test and urine iodine determination were carried out according to Jones and Di Sant'Agnese (1963); (5) peroral jejunal biopsies were performed with the paediatric Crosby and Kugler capsule (1957), and two specimens were obtained from each child at each session.

The jejunal specimens were studied: (a) by light microscopy stained with haematoxylin and eosin and with Masson's modified method (Brandborg et al., 1967); (b) biochemically for alkaline and acid phosphatases by Greenstein's method (1942), and for succinic dehydrogenase by Kun and Abood's method (1949) using a modified technique (Brito et al., 1967); (c) histochemically in 5 patients for alkaline phosphatase, acid phosphatase, and succinic dehydrogenase-according to
Barka and Anderson (1963); (d) by electron microscopy in 6 patients who were studied before treatment.

Electron microscopy specimens were processed as follows: small parts of the specimen were fixed in $1 \%$ osmium tetroxide, buffered in veronal acetate $\mathrm{pH} \mathrm{7.4}$. After dehydration in an ascending series of ethyl alcohol, mucosal fragments were embedded in Araldite, cut on a Porter Blum ultra-microtome equipped with glass or diamond knives and mounted in copper grids. After double staining with uranyl-acetate and lead hydroxide, they were examined in a Zeiss EM9 electron microscope.

One jejunal biopsy specimen from a child presenting with genital malformation but with normal growth and no hormonal disturbances, was used as a control for the electron microscopy study.

All children were treated with oral metronidazole given 


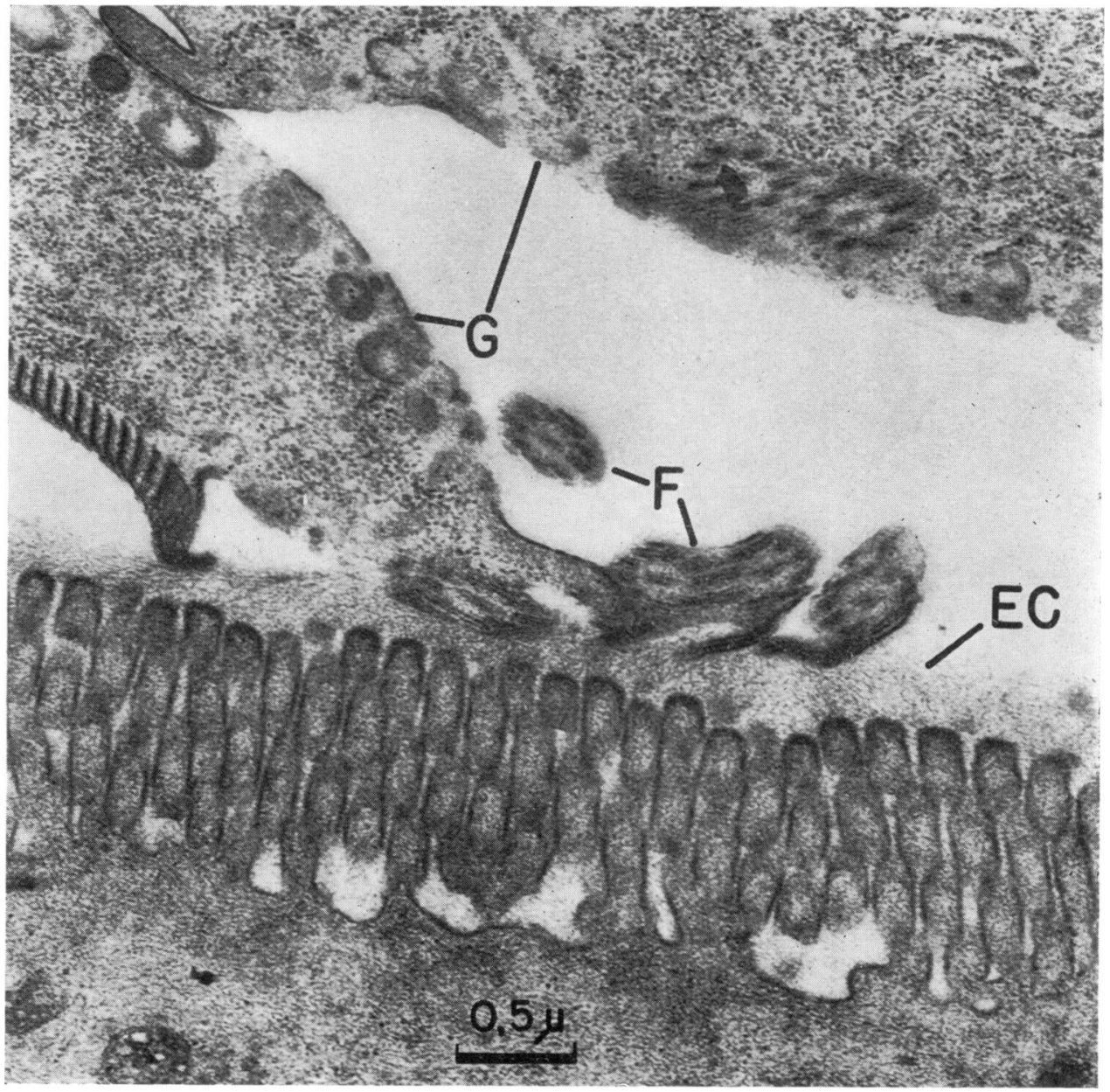

FIG. 2.-Electron micrograph showing G. lamblia $(G)$, flagellae $(F)$, over a prominent extraneous coat (EC). Branching and gaps at the microvilli basis are also seen.

during two 10 -day periods, with 10 days interval between them $(250,500$, and $750 \mathrm{mg}$./day to $0-1,2-4$, and 5-8 year old children, respectively). Examinations for parasites were carried out simultaneously on the duodenal juice and on three successive daily samples of stools in order to check treatment efficacy.

\section{Results}

A high degree of $G$. lamblia infestation was confirmed by the presence of protozoa, identified by light and electron microscopy in all jejunal biopsy specimens. The parasites, which had been present in large numbers in duodenal juice and stools, disappeared in all 11 cases after metronidazole treatment. Lipiodol absorption tests (Table I) showed an abnormal urine iodine excretion before treatment in 9 of our 11 cases. From these 9 cases,

\section{TABLE I}

Results of Lipiodol and D-xylose Absorption Tests Before and After Treatment

\begin{tabular}{l|c|c|c|c|c}
\hline $\begin{array}{c}\text { Absorption } \\
\text { Test }\end{array}$ & $\begin{array}{c}\text { No. } \\
\text { of } \\
\text { Patients }\end{array}$ & \multicolumn{2}{|c|}{ Before } & \multicolumn{2}{|c}{ After } \\
\cline { 2 - 5 } & 11 & 2 & 9 & 6 & 3 \\
\hline Lipiodol & 11 & 8 & 3 & 11 & - \\
D-xylose & Normal & Abnormal & Normal & Abnormal \\
\hline
\end{tabular}

$\star$ Urine specimens from two patients with abnormal lipiodol test were accidentally lost during post-treatment collection. 


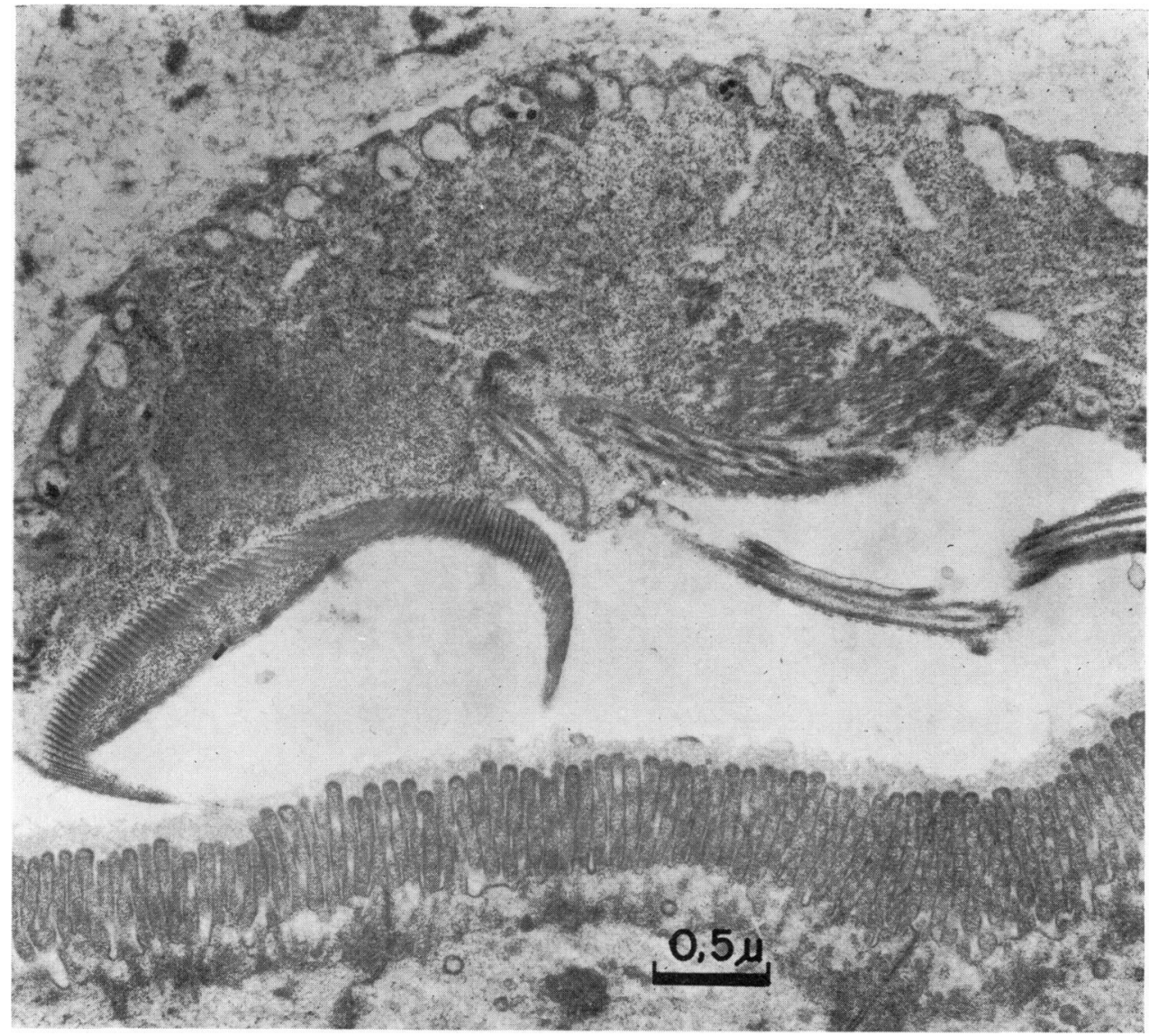

FIG. 3.-G. lamblia over jejunal mucosa interfere with the contact between the intestinal contents and microvilli. $A$ clear space is seen between the parasite and microvilli.

3 remained abrormal and 4 were normal after treatment; urine specimens from 2 abnormal cases were accidentally lost during post-treatment collection. D-xylose absorption test showed a recovery below $20 \%$ of the oral dose in 3 out of 11 cases before treatment, becoming normal after treatment.

Acid and alkaline phosphatase and succinic dehydrogenase activity was tested in jejunal mucosa in all cases by biochemical (Table II) and histochemical methods. Statistical analyses of biochemical results by the ' $t$ ' test showed no significant differences before and after treatment. Histochemical observations did not show any differences either.

Light microscopy of jejunal mucosa showed numerous parasites adherent to epithelial cells or attached to mucous filaments in the intervillous spaces. Masson's modified method failed to show
TABLE II

Biochemical Determinations of Enzymatic Activity in Jejunal Mucosa Before and After Treatment

\begin{tabular}{|c|c|c|c|c|}
\hline \multirow{2}{*}{ Enzyme } & \multirow{2}{*}{$\begin{array}{c}\text { No. of } \\
\text { Patients }\end{array}$} & \multicolumn{2}{|c|}{ Mean and Range Values } & \multirow[t]{2}{*}{$t$ Test } \\
\hline & & Before & After & \\
\hline $\begin{array}{l}\text { Succinic } \\
\text { dehydrogenase }^{\star}\end{array}$ & 9 & $\begin{array}{c}8 \cdot 03 \\
5 \cdot 58-10 \cdot 85\end{array}$ & $\begin{array}{c}6 \cdot 37 \\
2 \cdot 35-10 \cdot 26\end{array}$ & $\begin{array}{c}t 0.485 \\
\text { df } 7 \\
60<\mathrm{p}<70\end{array}$ \\
\hline $\begin{array}{l}\text { Alkaline } \\
\text { phosphatase }\end{array}$ & 11 & $\begin{array}{c}55 \cdot 51 \\
19 \cdot 50-88 \cdot 25\end{array}$ & $\begin{array}{c}64 \cdot 67 \\
38 \cdot 09-94 \cdot 37\end{array}$ & $\begin{array}{l}t 0.042 \\
\text { df } 10 \\
p>90\end{array}$ \\
\hline $\begin{array}{l}\text { Acid } \\
\text { phosphatase } f\end{array}$ & 10 & $\begin{array}{c}18 \cdot 91 \\
10 \cdot 65-47 \cdot 90\end{array}$ & $\begin{array}{c}13 \cdot 04 \\
4 \cdot 87-20 \cdot 00\end{array}$ & $\begin{array}{c}t 0.363 \\
\text { df } 9 \\
70<\mathrm{p}<80\end{array}$ \\
\hline
\end{tabular}

df $=$ degree of freedom; $p=$ probability; $\star=\mathrm{mg} . \mathrm{MTT} / \mathrm{g}$. mucosa; $\dagger=\mathrm{mg}$. tyrosine/g. mucosa. 


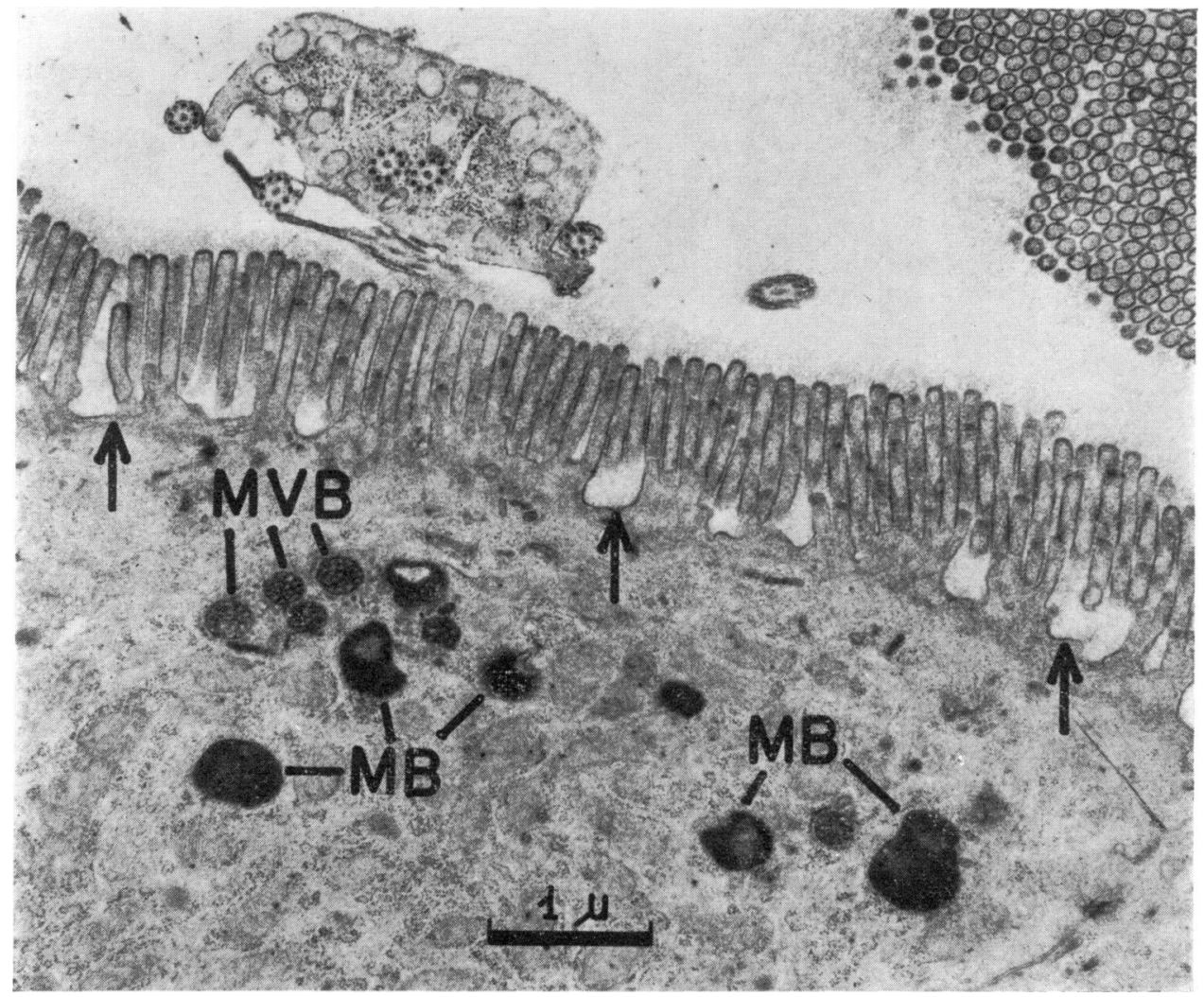

FIG. 4.-G. lamblia over jejunal epithelial cell which shows branching of microvilli and also gaps at the bases. Jejunal cell shows an increased number of multivesicular bodies (MVB) and dense bodies, probably lysosomes (MB).

tissue invasion by trophozoites. The number and appearance of the villi were, on the whole, normal or almost normal. Nevertheless the lamina propria was usually infiltrated by inflammatory cells, such as histiocytes, lymphocytes, plasma cells, and eosinophils. A variable degree of inflammatory change remained after treatment.

Electron micrographs of jejunal mucosa showed in all preparations that a large number of parasites had their adhesive disk directed towards the epithelial cells, being close to them or directly applied on the mucoid coat of the microvilli (Fig. 1 to 5).

Parasitic flagellae were seen over this coat, never penetrating through it (Fig. 2). When the parasite was attached to the epithelial cells, a clear space was present between the adhesive disk and the microvilli (Fig. 3) in contrast to the amorphous grey aspect material in the intestinal lumen covering the dorsal surface of the parasite. The ultrastructure of the jejunal epithelium showed the following differences from the control case: (a) thickening of the mucoid coat of the microvilli (Fig. 2); (b) microvilli branching and also gaps between their bases (Fig. 2-4); (c) an increased number of cyto- $\bar{\sigma}$ plasm dense bodies, probably lysosomes (Fig. 4); (d) intercellular spaces in some areas infiltrated with the lamina propria inflammatory cells, mainly $₹$ mononuclear ones (Fig. 5).

\section{Discussion}

This study showed that symptom-free children infested with $G$. lamblia had changes in the jejunal or mucosa and a mild degree of malabsorption, $\tilde{O}$ indicated by the lipiodol test which is a measure of $\mathrm{N}$ fat absorption (Barbieri et al., 1968). The total or partial return to normal of the results of the $D$-xylose and lipiodol tests is additional proof that the small intestine was damaged by $G$. lamblia in these cases. Thus, the children's healthy appearance obscured a certain degree of malabsorption.

Biochemical and histochemical studies of acid 


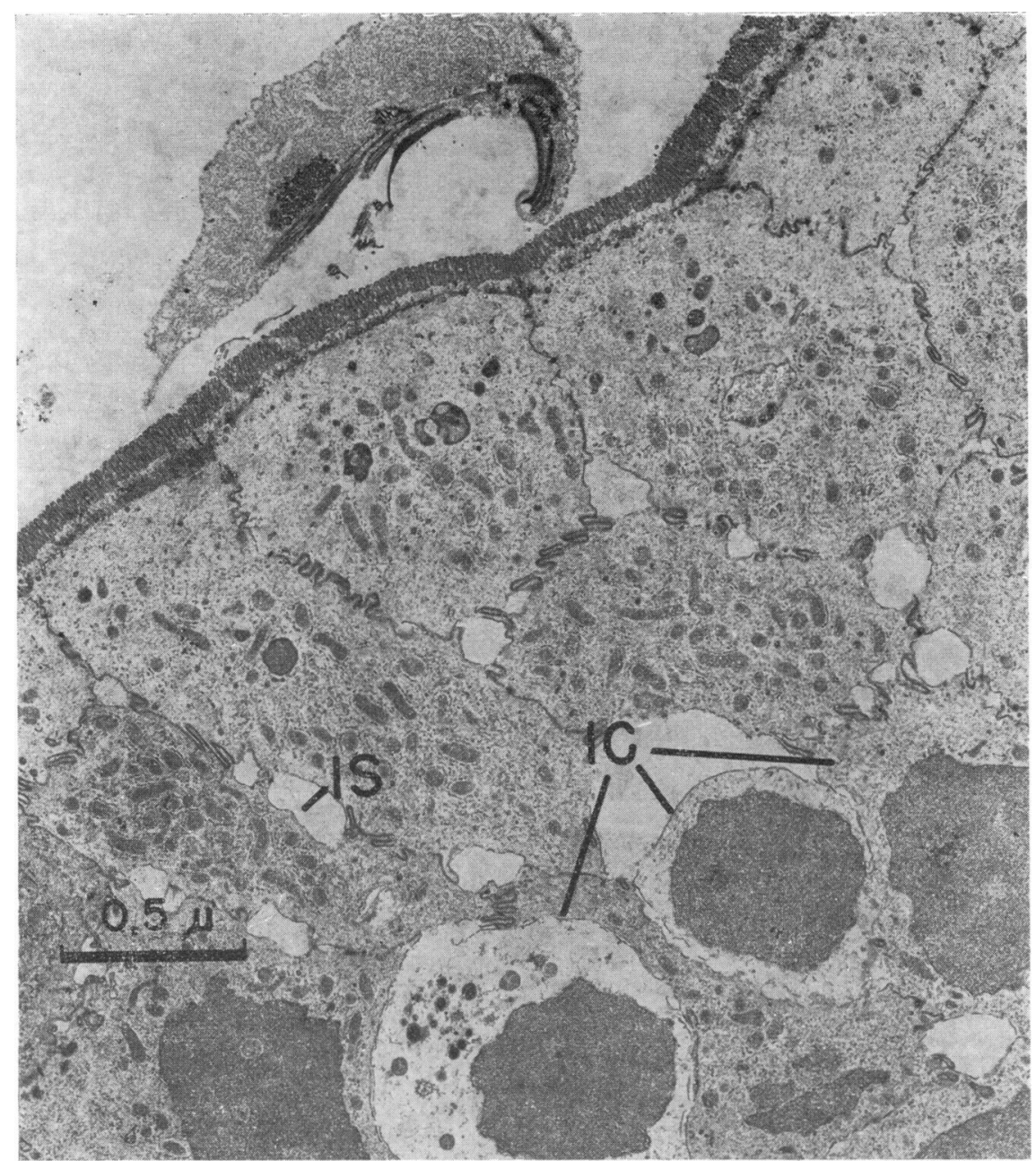

FIG. 5.-Elcctron micrograph showing G. lamblia over the jejunal epithelial surface. Intercellular spaces (IS) are enlarged and in some of them mononuclear inflammatory cells (IC) are seen.

phosphatase, alkaline phosphatase, and succinic dehydrogenase did not show significant differences in the basic enzymatic activities of the jejunal epithelia, before and after treatment.

This study suggests that the malabsorption of giardiasis may depend on mechanical blockade, thickening of mucoid coat, alterations in the microvilli, and cytoplasm of the epithelial cells, and inflammatory changes in the lamina propria. However, we believe that the main factors are mechanical blockade and/or nutritional competition by the parasite.

Mechanical blockade by $G$. lamblia, as mentioned by Véghelyi (1940), can be supported by the tropism of the parasite toward the mucosal surface, and by the adherence of the very active trophozoites to the epithelial cells (Fig. 1-3). In a one-dimension view (Fig. 1) a parasite appears to be blocking three cells. Related to the blockade mechanism one must consider the curious clear space presented by the electron micrographs (Fig. 3), where the amorphous gray material of the intestinal lumen, that surrounds the protozoon, is not seen. This suggests a hostparasite nutritional competition, in which uptake of nutrients by the parasite takes place on either the ventral or the dorsal trophozoite side. The last hypothesis can be supported by the presence of numerous vesicles, mostly located just below the parasite dorsal membrane. Though Friend (1966) considered these to be secretory organelles engaged 


\section{Barbieri, De Brito, Hoshino, Nascimento, Campos, Quarentei, and Marcondes}

in the coat formation of parasitic cysts, their function may also involve an intracellular digestive mechanism.

The role of an increased mucoid coat of the epithelial cells can be considered either as a cell defensive reaction (Ito, 1964) to avoid parasite invasion, or as an 'extraneous mucoid coat', as discussed by Johansen, Anderson, and Hadorn (1968) in a study of cystic fibrosis.

The branching and gaps in the microvilli, the increased numbers of cytoplasmic dense bodies, and the inflammatory process in the lamina propria (Fig. 2, 4, and 5) may be non-specific effects of irritation of the mucosa by G. lamblia.

We thank Dr. Clovis R. Takiguti who performed the statistical analysis.

\section{REFERENCES}

Ayres, N. (1960). Contribuição ao estudo da absorção intestinal dos protidios, gli cídios e lipidios. Thesis, Belém, Brazil.

Barbieri, D., Campos, J. V. M., Marcondes, E., and Quarentei, G. (1968). Behaviour of the lipiodol test in malabsorption syndromes. Arquivos de Gastroenterologica, 5, 173.

Barka, T., and Anderson, P. J. (1963). Histochemistry: theory, Practice and Bibliography, pp. 215-216, 242-243 and 313. Harper and Row, New York.

Brandborg, L. L., Tankersley, C. B., Gottlieb, S., Barancik, M., and Sartor, V. E. (1967). Histological demonstration of mucosal invasion by Giardia lamblia in man. Gastroenterology, 52, 143.

Brito, T. de., Penna, D. O., Pereira, V. C., and Hoshino, S. (1967). Kidney biopsies in human leptospirosis: a biochemical and electron microscopy study. Virchows Archiv für pathologische Anatomie und Physiologie und für klinische Medizin, 343, 124.

Burdzińska-Golowin, J., Lewandowska, J., and Misiukowa, G. (1967). Clinical forms of lambliasis in small children. (Polish.) Pediatria Polska, 42, 685.

Cameron, A. H., Astley, R., Hallowell, N., Rawson, A. B., Miller, C. G., French, J. M., and Hubble, D. V. (1962). Duodenojejunal biopsy in the investigation of children with coeliac disease. Quarterly fournal of Medicine, 31, 125.

Cantor, D., Biempica, L., Toccalino, H., and O'Donnell, J. C. (1967). Small intestine studies in Giardiasis. American fournal of Gastroenterology, 47, 134

Cortner, J. A. (1959). Giardiasis: a cause of celiac syndrome. American fournal of Diseases of Children, 98, 311.
Court, J. M., and Anderson, C. M. (1959). The pathogenesis of Giardia lamblia in children. Medical fournal of Australia, 2, 은 436.

Crosby, W. H., and Kugler, H. W. (1957). Intraluminal biopsy of $\overrightarrow{\overrightarrow{\vec{D}}}$ small intestine; the intestinal biopsy capsule. American fournal of Digestive Diseases, 2, 236.

Frankel, S., and Reitman, S. (1963). Gradwohl's Clinical Laboratory Methods and Diagnosis. Vol. 1, p. 231, 6th ed. C. V. Mosby, $\overline{\bar{\omega}}$ St. Louis.

Friend, D. S. (1966). The fine structure of giardia muris. fournal $\mathbb{D}$ of Cell Biology, 29, 317.

Greenstein, J. P. (1942). Distribution of acid and alkaline phos- ڤొ phatase in tumors, normal tissues, and the tissues of tumorbearing rats and mice. Fournal of the National Cancer Institute, 2,511 .

Hoskins, L. C., Winawer, S. J. , Broitman, S. A., Gottlieb, L. S., and $\overrightarrow{\vec{\omega}}$ Zamcheck, N. (1967). Clinical giardiasis and intestinal malabsorption. Gastroenterology, 53, 265.

Ito, S. (1964). The surface coating of enteric microvilli. (Abstr.) Anatomical Record, 148, 294.

Johansen, P. G., Anderson, C. M., and Hadorn, B. (1968). Cystic $\overrightarrow{0}$ fibrosis of the pancreas. A generalised disturbance of water and electrolyte movement in exocrine tissues. Lancet, 1, 455. A

Jones, W. O., and Di Sant'Agnese, P. A. (1963). Laboratory aids N in the diagnosis of malabsorption in pediatrics. I. Lipiodol absorption as a simple test for steatorrhoea. Fournal of Pediatrics, 62, 44.

Kun, E., and Abood, L. G. (1949). Colorimetric estimation of succinic dehydrogenase by triphenyltetrazolium chloride. Science, 109, 144.

Morecki, R., and Parker, J. G. (1967). Ultrastructural studies of the human Giardia lamblia and subjacent jejunal mucosa in a subject with steatorrhea. Gastroenterology, 52, 151.

Takano, J., and Yardley, J. H. (1965). Jejunal lesions in patients with giardiasis and malabsorption: an electron microscopic study. Bulletin of the fohns Hopkins Hospital, 116, 413.

Véghelyi, P. V. (1940). Giardiasis. American fournal of Diseases of Children, 59, 793.

Verri, B., Cottafava, F., Gemme, G., and Vignolo, L. (1965). Malassorbimento intestinale dei carboidrati nella lambliasi: Studio di 8 casi. Minerva Pediatrica, 17, 1481.

Yardley, J. H., Takano, J., and Hendrix, T. R. (1964). Epithelial and other mucosal lesions of the jejunum in giardiasis. Jejunal biopsy studies. Bulletin of the fohns Hopkins Hospital. 115, 389.

Zamcheck, N., Hoskins, L. C., Winawer, S. J., Broitman, S. A., and Gottlieb, L. S. (1963). Histology and ultrastructure of the parasite and the intestinal mucosa in human giardiasis: effects of atabrine therapy. (Abstr.) Gastroenterology, 44, 860.

Correspondence to Dr. D. Barbieri, Clínica Pediatrica, Hospital das Clínicas, Av. Dr. Eneias de Carvalho Aguiar, São Paulo, Brazil. 